\title{
Fisheries in the Context of Attaining Sustainable Development Goals (SDGs) in Bangladesh: COVID-19 Impacts and Future Prospects
}

\author{
Atiqur Rahman Sunny 1,2,*(D), Mahmudul Hasan Mithun ${ }^{3}$, Shamsul Haque Prodhan ${ }^{1}$, Md. Ashrafuzzaman ${ }^{1}(\mathbb{D}$, \\ Syed Mohammad Aminur Rahman ${ }^{4}$, Md Masum Billah ${ }^{5}$, Monayem Hussain ${ }^{6}$, Khandaker Jafor Ahmed ${ }^{4}(\mathbb{D}$, \\ Sharif Ahmed Sazzad 7 ${ }^{\text {(D) }}$ Md Tariqul Alam ${ }^{8}$, , Aminur Rashid ${ }^{8}$ and Mohammad Mosarof Hossain ${ }^{9}$
}

Citation: Sunny, A.R.; Mithun, M.H.; Prodhan, S.H.; Ashrafuzzaman, M.; Rahman, S.M.A.; Billah, M.M.; Hussain, M.; Ahmed, K.J.; Sazzad, S.A.; Alam, M.T.; et al. Fisheries in the Context of Attaining Sustainable Development Goals (SDGs) in Bangladesh: COVID-19 Impacts and Future Prospects. Sustainability 2021, 13, 9912. https://doi.org/10.3390/ su13179912

Academic Editor: Shervin Hashemi

Received: 8 July 2021

Accepted: 30 August 2021

Published: 3 September 2021

Publisher's Note: MDPI stays neutral with regard to jurisdictional claims in published maps and institutional affiliations.

Copyright: (C) 2021 by the authors Licensee MDPI, Basel, Switzerland. This article is an open access article distributed under the terms and conditions of the Creative Commons Attribution (CC BY) license (https:// creativecommons.org/licenses/by/ $4.0 /)$.
1 Department of Genetic Engineering and Biotechnology, Shahjalal University of Science and Technology, Sylhet 3100, Bangladesh; shamsulhp@gmail.com (S.H.P.); azamanbt@gmail.com (M.A.)

2 Suchana Project, WorldFish, Bangladesh Office, Gulshan, Dhaka 1213, Bangladesh

3 Bangladesh Fisheries Research Institute, Mymensing 2201, Bangladesh; mithun622bsmrau@gmail.com

4 Department of Geography, Environment and Population, The University of Adelaide, Adelaide, SA 5005, Australia; syedamin22nd@gmail.com (S.M.A.R.); khandaker.ahmed@adelaide.edu.au (K.J.A.)

5 Ministry of Education, Bangladesh Secretariat, Dhaka 1000, Bangladesh; masumbahadur@gmail.com

6 Ecofish-1l Project, WorldFish, Bangladesh Office, Gulshan, Dhaka 1213, Bangladesh; hussain.monayem@gmail.com

7 Pathfinder Agro and Fisheries Consultation Center, Sylhet 3100, Bangladesh; sazzad139@gmail.com

8 Department of Aquaculture, Sylhet Agricultural University, Sylhet 3100, Bangladesh; talam.aq@sau.ac.bd (M.T.A.); aminur0579sau@gmail.com (A.R.)

9 Department of Coastal and Marine Fisheries, Sylhet Agricultural University, Sylhet 3100, Bangladesh; mosarofmh.cmf@sau.ac.bd

* Correspondence: atiksunny@yahoo.com

Abstract: Fisheries and the aquaculture sector can play a significant role in the achievement of several of the goals of the 2030 Sustainable Development agenda. However, the current COVID-19 situation can negatively impact the fisheries sector, impeding the pace of the achievement of development goals. Therefore, this paper highlighted the performance and challenges of the fisheries sector in Bangladesh, emphasising the impact of COVID-19 and the significance of this sector for achieving the Sustainable Development Goals (SDGs), through primary fieldwork and secondary data. The total fish production in the country has increased more than six times over the last three decades (7.54 to 43.84 lakh MT) with improved culture techniques and extension services. Inland closed water contributions have increased to $16 \%$, while inland open water has declined to $10 \%$, and marine fisheries have dropped to 6\% over the past 18 financial years (2000-2001 to 2018-2019). COVID-19, a significant health crisis, has also affected various issues associated with aquatic resources and communities. Transportation obstacles and complexity in the food supply, difficulty in starting production, labour crisis, sudden illness, insufficient consumer demand, commodity price hikes, creditor's pressure, and reduced income were identified as COVID-19 drivers affecting the fisheries sector. The combined effect of these drivers poses a significant threat to a number of the SDGs, such as income (SDG1), nutrition (SDG2), and food security (SDG3 and SDG12), which require immediate and comprehensive action. Several recommendations were discussed, the implementation of which are important to the achievement of the SDGs and the improved management of the aquatic sector (SDG14-life below, and SDG16-life above water).

Keywords: fisheries; aquaculture; food security; COVID-19; SDGs; Bangladesh

\section{Introduction}

Bangladesh, a nation blessed with diverse aquatic resources, is located in Southeast Asia, between $20^{\circ} 34^{\prime}$ to $26^{\circ} 38^{\prime} \mathrm{N}$ latitude and $88^{\circ \prime} 01^{\prime}$ to $92^{\circ} 42^{\prime}$ E longitude, and has an 
area of $147,570 \mathrm{~km}^{2}$ [1]. It is one of the top fish-producing countries globally, with its vast inland, coastal, and marine water resources [2]. The fisheries sector in Bangladesh is one of the most productive and dynamic sectors, which has played an increasingly significant role in the economy for the last few decades [3,4]. Since its independence in 1971, Bangladesh has achieved tremendous progress in the fisheries sector, contributing significantly to the promotion of the dependent community's food security and socioeconomic status [5,6], which are crucially highlighted in the UN's Sustainable Development Goals (SDGs). There are different types of interactions between SDGs and aquatic food production systems and the well-being of the dependent community. Fish from capture fisheries and aquaculture help marginalised people maintain their food supply and livelihoods in terms of nutritional security, good health and well-being, poverty alleviation, and reduced inequalities. Around $12 \%$ of the total population of Bangladesh is involved in the fisheries sector directly and indirectly [7], contributing 3.50\% to the national GDP, $25.72 \%$ to the agricultural GDP $[7,8]$ and providing a significant share of animal proteins.

The diversified fisheries resources of Bangladesh are mainly divided into two groups: inland and marine fisheries [3,9]. Inland fisheries have two sub-sectors, inland capture and inland culture fisheries, covering 3.89 and 0.82 million ha, respectively (Table 1). The inland open water habitats include rivers and estuaries (853,863 ha), the Sundarbans (177,700 ha), beels (114,161 ha), Kaptai Lake (68,800 ha), and floodplains (2,675,758 ha) (Figure 1). On the other hand, inland closed water habitats include ponds (397,775 ha), seasonal cultured water bodies (144,217 ha), Baor (5671 ha), shrimp/prawn farms (258,553 ha), crab farms (9377 ha), pen culture (6330 ha), and 1.76 lakh $^{3}$ for cage culture [7]. In 2018-2019, the inland capture, inland culture, and marine fisheries contributed approximately $28.19 \%$, $56.76 \%$, and $15.05 \%$ of the country's total fisheries production, respectively [7] (Table 1). Over the last three decades, the total fish production increased more than six times from 7.54 MT in 1983-1984 to BDT 43.84 lakh MT in 2018-2019. In 2018-2019, the country earned BDT 425,031.00 by exporting almost 73.17 thousand MT of fish and fishery products [7].

Table 1. Sector-wise fish production and water areas of Bangladesh in 2018-2019.

\begin{tabular}{|c|c|c|c|c|}
\hline Fisheries Types & Fisheries Sector & Water Area (ha) & Production (MT) & Production $(\%)$ \\
\hline \multirow[b]{2}{*}{ Inland Fisheries } & $\begin{array}{l}\text { Inland open water (capture) } \\
\text { rivers, estuaries, Sundarbans, } \\
\text { beels, Kaptai Lake, floodplains }\end{array}$ & $3,890,282$ & $1,235,709$ & 28.19 \\
\hline & $\begin{array}{l}\text { Inland closed water (culture) } \\
\text { pond, seasonal cultured water } \\
\text { body, Baor, shrimp/prawn farm, } \\
\text { pen culture, cage culture }\end{array}$ & 821,923 & $2,488,601$ & 56.76 \\
\hline Total (Inland) & & $4,712,205$ & $3,724,310$ & 84.95 \\
\hline \multirow{2}{*}{ Marine Fisheries } & Industrial (trawl) fishing & & 107,236 & 2.45 \\
\hline & Artisanal fishing & & 552,675 & 12.61 \\
\hline Total (Marine) & & & 659,911 & 15.05 \\
\hline \multicolumn{2}{|c|}{ Total production (Inland + Marine) } & & $4,384,221$ & 100 \\
\hline
\end{tabular}

Data source: Department of Fisheries (DoF) [7].

Although inland capture fisheries are an important source of total fish production, they have reduced remarkably due to several anthropogenic interventions and natural causes, e.g., pollution, over-exploitation, destructive fishing, and habitat degradation [10]. In 1983-1984, the total production of inland capture and culture fisheries was $62.59 \%$ and $15.53 \%$, respectively, whereas, in 2018-2019, inland capture fisheries sharply dropped to $28.19 \%$, and inland culture fisheries increased to $56.76 \%$ [7]. However, in recent years, several socio-eco-friendly programs were implemented to increase the productivity of inland open waters, such as a community-based fisheries management program, the establishment of fish sanctuaries, beel nursery management, the stocking of fingerlings in water bodies, the restoration of the aquatic habitats, and an increase in water area under 
cage and pen farming [11]. Bangladesh also has a huge potential for marine fisheries, comprising artisanal (fishing below $40 \mathrm{~m}$ depth) and industrial (trawl fishing above $40 \mathrm{~m}$ depth) fisheries and coastal sub-sectors. Despite having a long coastline (ca. $710 \mathrm{~km}$ ) and a large marine water area, the marine fisheries sector is underdeveloped compared to other business sectors in Bangladesh [12]. Nonetheless, the recently settled maritime boundary with Myanmar and India, up to 200 nautical miles from the coastline, comprising $118,813 \mathrm{~km}^{2}$ of maritime water, represent a huge blue economy development prospect. The potentiality and challenges of Bangladesh's fisheries and aquaculture sector were reviewed by Ghose (2014) up to 2012 and Shamsuzzaman et al. (2017) up to 2015. The impact of the COVID-19 pandemic on that sector is yet to be explored.

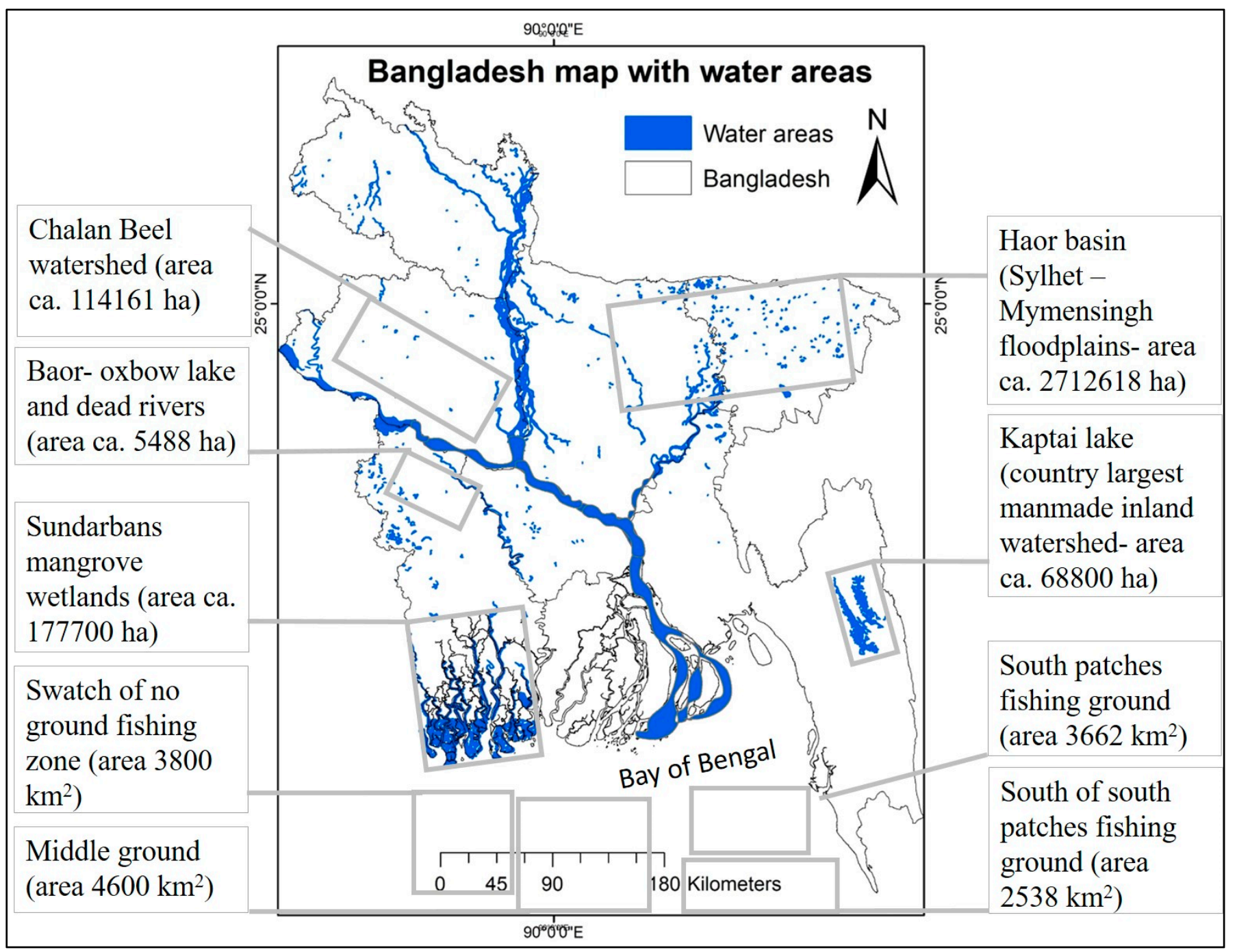

Figure 1. Aquatic resources and focal natural waters in Bangladesh, including major fishing grounds in the Bay of Bengal. This map illustrates the tentative location of major water areas of Bangladesh and does not necessarily reflect any precise administrative and or political boundary line with neighbouring countries.

This aquaculture and fisheries nexus requires observation through the lens of the COVID-19 pandemic because it is likely to impact the aquatic food system and the resilience of the dependent communities in Bangladesh. Bangladesh is struggling to cope with the adverse effects of COVID-19 due to its resource constraints. As of 1 August 2021, the country has confirmed 1,264,328 COVID-19 positive cases, 1,093,266 recovered cases, and the total death toll of 20,916. Bangladesh has adopted so-called preventive measures, such as social distancing, lockdowns, local and international travel restrictions, and work from 
home. These initiatives reduce the household income mainly for the wage earners and, as a result, people are facing difficulties managing their living expenses. Indirectly, COVID-19 has affected aquatic food production as well. The restrictions in movement, difficulty in fish and input transportation, low consumer demand, unsold mature fish, low market prices, disruption in the new farming cycle, the labour crisis, limited attendance of the service provider, debt cycle, ban period, and disease susceptibility have all impacted the livelihood of fish farmers, fishers, and associated stakeholders. There are limited studies on the impacts of the COVID-19 pandemic on small-scale fisheries and aquaculture. A more in-depth focus is needed to obtain a general overview of the impacts of this pandemic on the different sub-sectors of fisheries, dependent communities, and associated stakeholders. Aquaculture and fisheries sectors provide crucial provisions to the wider society and have solid linkages for achieving several SDGs within the context of Bangladesh. Nevertheless, literature addressing the linkage of fisheries and the aquaculture sector with relevance to development (e.g., the economic, social, and environmental dimensions of sustainability) and the achievement of the SDGs are also limited. Therefore, this research aimed to highlight the potential and challenges of the fisheries and aquaculture sector in Bangladesh by bridging the gap of the existing situation (e.g., provide an update on the status of the sector, the COVID-19 pandemic impact on the aquatic resource system, and the involved stakeholders and dependent community). This attempt also reflected this sector's potential linkage and significance for achieving several SDGs in Bangladesh because of the COVID19 pandemic. Finally, this study recommends plans and policies to aid in the recovery of the fisheries sector following the COVID-19 pandemic and analogous inversion in the future.

\section{Materials and Methods}

\subsection{Study Areas}

This cross-sectional study was purposively conducted in 15 communities of 10 districts under eight administrative divisions (Table 2).

Table 2. Selected study areas in eight administrative divisions in Bangladesh.

\begin{tabular}{lll}
\hline \multicolumn{1}{c}{ Divisions $(\mathbf{n}=\mathbf{8})$} & \multicolumn{1}{c}{ Districts $(\mathbf{n}=\mathbf{1 0})$} & \multicolumn{1}{c}{ Communities $(\mathbf{n}=\mathbf{1 5})$} \\
\hline \multirow{2}{*}{ Khulna } & Bagerhat & Chila and Joymonigul \\
Rangpur & Chuadanga & Darsana \\
Rajshahi & Gaibanda & Palashbari \\
Dhaka & Pabna & Bera \\
Chattogram & Narsingdi & Polash and Narsingdi Sadar \\
Barishal & Chandpur & Haimchar \\
Sylhet & Laxmipur & Char Alexandar \\
Mymensingh & Barishal & Kawarchar and Laharhat \\
\hline
\end{tabular}

\subsection{Empirical Primary Data Collection}

This study on Bangladesh's fisheries and aquaculture fishing communities emerged while the COVID-19 pandemic remained pervasive within the country. Hence, the study was based on field data administrating, such as key informant interviews (KIIs), focus group discussion (FGDs), in-depth interviews, and a primary survey questionnaire. In this case, appropriate ethical consideration was maintained, and the respondents' enthusiastic participation during the field visit, data collection, and preservation was ensured.

\subsubsection{In-Depth Tete-a-Tete Interviews}

As the COVID-19 scenario of the country was gradually deteriorating and the government was enforcing various restrictions, it was difficult to move across the state for in-depth tete-a-tete interviews. In total, 50 in-depth tete-a-tete interviews were conducted with the aquaculture, fisheries, and coastal communities, hatcheries and fish production 
farmers to assess the impact of the pandemic on the fisheries sector. The COVID-19 health protocols and social distancing were strictly maintained during the field site visits.

\subsubsection{Key Informant Interviews}

We conducted 50 key informant interviews (KIIs) with fisheries-dependent communities (fish, shrimp, crab, snail, and oyster harvesters) to determine the impacts of the COVID-19 pandemic. With strict lockdown and shutdowns, it was challenging to physically meet with eminent and noteworthy officials and various stakeholders for face-to-face interviews. In that case, around 30 telephonic stakeholder interviews were also conducted to cross-check the data accuracy.

\subsubsection{Focus Group Discussion}

A total of 22 focus group discussions (FGDs) were conducted to understand the context of COVID-19 and the prospects of the fisheries sector tackling the health and food crisis. Respondents provided some exciting information during the FGDs. Participants from diverse departments of aquaculture and fisheries of the selected districts were considered for the FGDs. In every FGD, 6-8 respondents participated, ensuring the World Health Organization's COVID-19 health protocol was followed, face masks were worn, and social distance was maintained.

\subsection{Secondary Data Gathering}

Secondary data on the COVID-19 pandemic was collected from the Directorate General of Health Services (DGHS), Institute of Epidemiology and Disease Control and Research (IEDCR). Relevant fisheries- and aquaculture-related secondary data, including, but not limited, to fish production, and food demand and supply, was collected from the Department of Fisheries (DoF). Other significant data sources were scientific articles and technical reports.

\subsection{Data Analysis}

The recording of the KIIs and FGDs were transcribed and analysed. The other content and the summary of the data were analysed to develop a conceptual understanding of this study. MS Excel (version 2016) was used to formulate the quantitative data using descriptive statistics in frequencies and percentages. The data were presented in graphs, bars charts, and tables.

\section{Present Status of Inland Fisheries Resources of Bangladesh}

\subsection{Inland Open Water Fish Production in Bangladesh}

Inland fisheries refer to the capturing and culturing of fishes in inland water. Bangladesh ranked third in inland captured fisheries and ranked fifth in world aquaculture production [7]. However, in production from single-species culture, explicitly the monoculturing of Tilapia (Oreaochromis niloticus), Bangladesh ranked fourth in the world and became third in Asia. The national fish, hilsa (Tenualosa ilisha), contributed around $2.15 \%$ to the total fish production in the country, with a total production of 5.33 lakh MT, and was awarded the national Geographical Indication Registration Certificate [7,8].

Inland fisheries are sub-divided into inland capture (fishing from inland open water) and inland culture fisheries (aquaculture). The inland capture fishery contains five habitats: the river estuary, the Sundarbans (the world's largest mangrove forest), beels, Kaptai Lake, and floodplains. The inland culture fishery contains seven types of habitats, such as ponds, seasonal culture water bodies, baors, shrimp and prawn farms, crab farms, pen culture, and cage culture [7]. In 2018-2019, the total fish production in Bangladesh was reported as 4.38 million MT, of which 1.23 million MT (28.19\%) were from inland open waters, 2.48 million MT (56.76\%) from inland closed waters, and 0.65 million MT (15.05\%) from marine fisheries (Table 1). Inland open water fisheries are still a significant source of total fish production, but their share has declined from 38.68\% in 2000-2001 [13] to only $28.19 \%$ 
in 2018-2019 [7]. Conversely, inland closed water fisheries contributions have increased from $40.01 \%$ in $2000-2001$ [13] to 56.76\% in 2018-2019 [7]. In recent years, the average yield (annual fish harvest per ha in metric tons) in open inland waters improved sharply (Table 3). The beel fishery has a high productivity of $875 \mathrm{~kg} /$ ha compared to the other habitats of inland open water (Table 3). A total of 293 fish species noted by Hossain et al. 2012 [14], and 260 taxa with 12 exotic fish and 24 prawn species, were recorded in Bangladesh [15] and are known to inhabit the nation's freshwaters. Significant carp species, such as catla (Catla catla), rui (Labeo rohita), mrigal (Cirrhinus cirrhosus), and kalbasu (Labeo calbasu), along with some exotic carp species, such as silver carp (Hypophthalmichthys molitrix), grass carp (Ctenopharyngodon idellus), and common carp (Cyprinus carpio), are the most available carp species found in the market. About 40-50 small indigenous fish species grow to a maximum length of $25 \mathrm{~cm}$ [16]. Some more commonly found species of this variety include titputi (Puntius ticto), mola (Amblypharyngodon mola), kholisha (Colisa lalius), koi (Anabas testudineus), and baila (Glossogobius giuris). Several small indigenous species of fish are now endangered or critically endangered in Bangladesh [14], although the inland water resources of Bangladesh offer significant potential for the development of freshwater capture and culture fisheries $[17,18]$. The catch from the inland capture fishery is noteworthy, especially for fish supply and employment in rural areas.

Table 3. Inland open water fish production of Bangladesh in 2018-2019 [7].

\begin{tabular}{cccc}
\hline $\begin{array}{l}\text { Inland Open Water } \\
\text { (Capture Fisheries) }\end{array}$ & Water Area (ha) & Production (MT) & Productivity (Kg/ha) \\
\hline Rivers and Estuaries & 853,863 & 320,598 & 381 \\
The Sundarbans & 177,700 & 18,225 & 103 \\
Beel & 114,161 & 99,197 & 875 \\
Kaptai Lake & 68,800 & 10,152 & 154 \\
Floodplains & $2,712,618$ & 768,367 & 292 \\
\hline
\end{tabular}

Data source: Department of Fisheries (DoF) [7].

\subsection{Inland Closed Water (Culture) Fish Production of Bangladesh}

The inland aquaculture has generally experienced the fastest growth in the country, with the adoption of advanced culture technologies, species intensification, and improvement of farming systems, particularly in pond aquaculture, among various segments of the fisheries sub-sector $[19,20]$. However, around half of the fish are provided by aquaculture for direct human consumption and is set to grow further. The aquaculture industry boosts the economy with increasing production capacity and high export opportunities. The average growth rate of the fisheries sector over the last 10 years was about 5.01\%, while aquaculture grew by $8.59 \%$. Generally, two types of aquaculture are practised in Bangladesh, namely, freshwater and coastal aquaculture. Marine aquaculture is growing in the country, and the farming of marine fish is significant. Freshwater aquaculture is mainly comprised of pond farming of carps (Indian major and Chinese carps), pangasius (Pangasius pangasius) and other catfishes, tilapia (Oreochromis nilotics), Mekong climbing perch (Anabas testudineus), and several other domesticated fish. Pen and cage culture are two new cultivation approaches in Bangladesh and contributed to 12,361 MT (0.28\%) and 3802 MT $(0.09 \%)$ to the total fish production in 2018-2019, respectively (Table 4$)$. These new methods have the highest potential for increasing fish production in Bangladesh. Total fish production in pen culture declined in the previous years in 2018-2019, but cage culture is becoming more popular and the production rate has increased in recent years. Coastal aquaculture is mainly comprised of shrimp and prawn farming in ghers (a coastal pond or enclosures with dug-out soil used to create dykes) and, in 2018-2019, the total production of shrimp and prawn was about 258,039 MT. In Bangladesh, aquaculture production systems are mainly extensive and improved extensive, with some semi-intensive and intensive systems in very few cases [17]. The current aquaculture productions for the pond, seasonal water body, baor (oxbow lake) and shrimp ghers are 4.96, 1.50, 1.82, and 0.99 (MT/ha), 
respectively (Table 4). Inland pond culture represents the mainstay of aquaculture in Bangladesh, accounting for more than $80 \%$ of the total recorded aquaculture production. Pond aquaculture is the most practised type of closed water fishery in Bangladesh and contributed 45.04\% (1,974,632 MT) to total fish production in 2018-2019 [7]. The main cultured species in the coastal areas of Bangladesh are giant tiger prawn (Penaeus monodon) and giant river prawn (Macrobrachium rosenbergii) [21].

Table 4. Inland closed water fish production in 2018-2019 in Bangladesh.

\begin{tabular}{cccc}
\hline $\begin{array}{c}\text { Inland Closed } \\
\text { Water }\end{array}$ & $\begin{array}{c}\text { Water Area } \\
\text { (ha) }\end{array}$ & $\begin{array}{c}\text { Production } \\
\text { (MT) }\end{array}$ & $\begin{array}{c}\text { Productivity } \\
\text { (Kg/ha) }\end{array}$ \\
\hline Pond & 397,775 & $1,974,632$ & 4964 \\
Seasonal cultured- water body & 144,217 & 217,340 & 1507 \\
Baor & 5671 & 10,343 & 1824 \\
Shrimp/Prawn farm & 258,553 & 258,039 & 998 \\
Crab farm (capture and fattening culture) & 9377 & 12,084 & 1289 \\
Pen culture & 6330 & 12,361 & 1953 \\
Cage culture & $176,000 \mathrm{~m}^{3}$ & 3802 & $22 \mathrm{~kg} / \mathrm{m}^{3}$ \\
\hline
\end{tabular}

Data source: Department of Fisheries (DoF) [7].

\section{Shrimp and Prawn Production Trends in Bangladesh}

Shrimp and prawn are major export items and are mainly produced in coastal districts, such as Khulna, Satkhira, Barishal, Patuakhali, Bagerhat, Bhola, Chattogram, and Cox's Bazar. As a result of increasing demand and prices, shrimp culture began expanding in the 1970s, aiming mainly at the export markets [22]. It was reported that the shrimp and prawn culture area had expanded from 217,177 ha in 2005-2006 to over 258,553 ha in 2018-2019. The production of shrimp has increased from 211,010 MT to 239,855 MT (Figure 2), and the average production of shrimp and prawn is $998 \mathrm{~kg} / \mathrm{ha}$ [7]. In the Khulna region, shrimp is cultured in a modified rice field (also called gher), while in Cox's Bazar, shrimp and salt are produced alternately $[23,24]$. However, different programs and development projects are also being implemented for the increased production and promotion of shrimp aquaculture. The shrimp cluster farming approach was popularised for enhancing shrimp production and promoting a business-friendly supply chain by adopting good aquaculture practices. The government has maintained standards in all stages of fish and shrimp production, processing, and export. In Bangladesh, shrimp culture technology has intensified in recent years, but the production level has not increased satisfactorily. One of the main reasons for that is the unavailability of good quality post-larvae (PL) and feed. The specific, pathogenfree post-larvae should be supplied broadly to shrimp farms to reduce the different viral and bacterial disease related mortality.

\subsection{Marine Fisheries Production in Bangladesh}

The Bay of Bengal is blessed with rich coastal and marine ecosystems, hosting a wide range of biodiversity, including fish, shrimp, molluscs, crabs, mammals, reptiles, seaweeds, etc. (Figure 3) $[25,26]$. It has the potential to contribute to the economy of Bangladesh by the exploration, exploitation, and management of living and non-living resources [27,28]. Most specifically, after the recent decision of the Bangladesh-Myanmar maritime boundary in 2012 and the decision of the India-Bangladesh maritime boundary in 2014, the country established sovereign rights to more than $118,813 \mathrm{~km}^{2}$ of territorial sea, 200 nautical miles of Exclusive Economic Zone (EEZ), and an assortment of living and non-living resources under the continental shelf up to 354 nautical miles from the Chittagong coasts. 


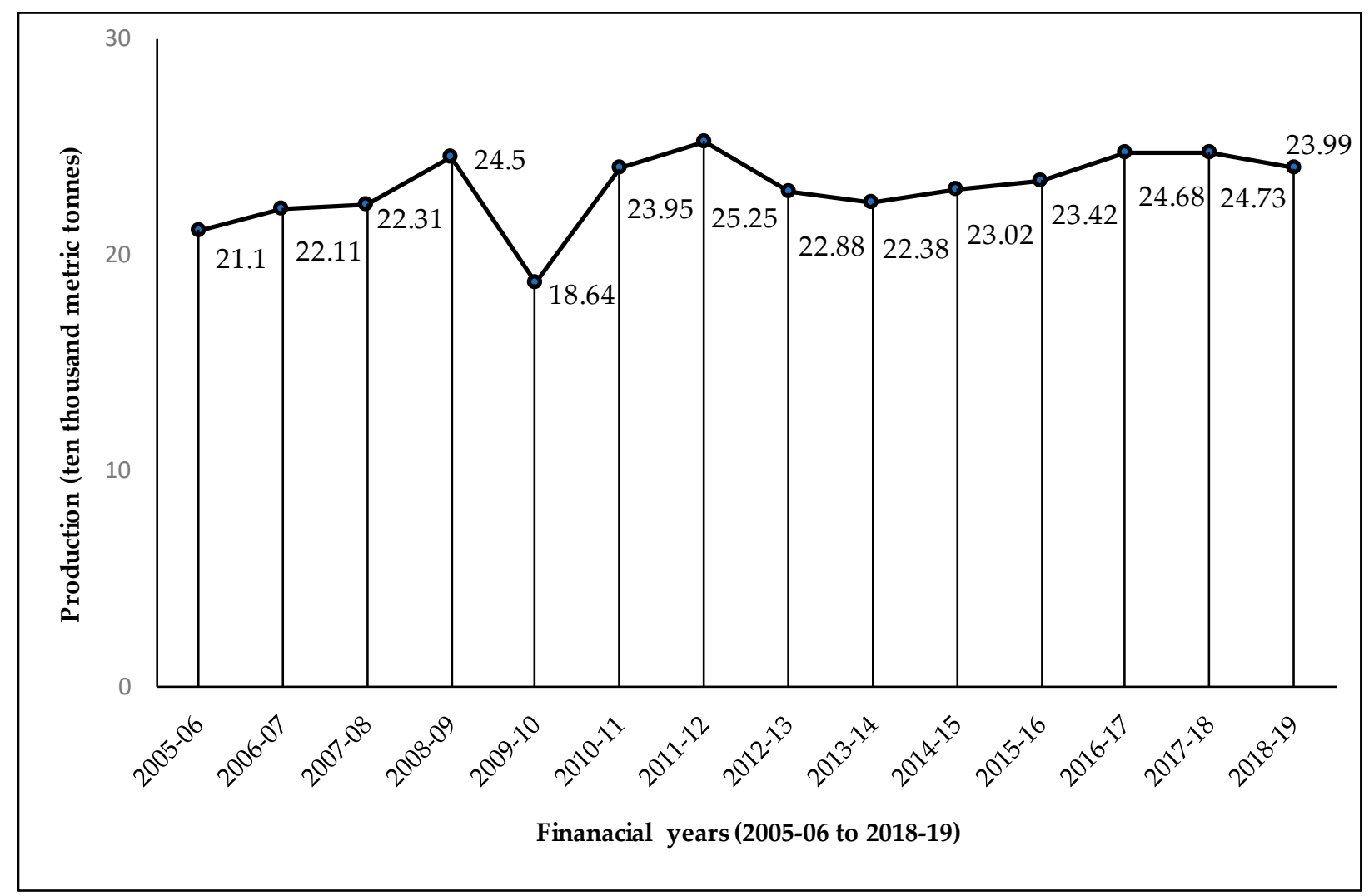

Figure 2. The trend of shrimp/prawn production from 2005-2006 to 2018-2019. Data source: Department of Fisheries (DoF) [7].

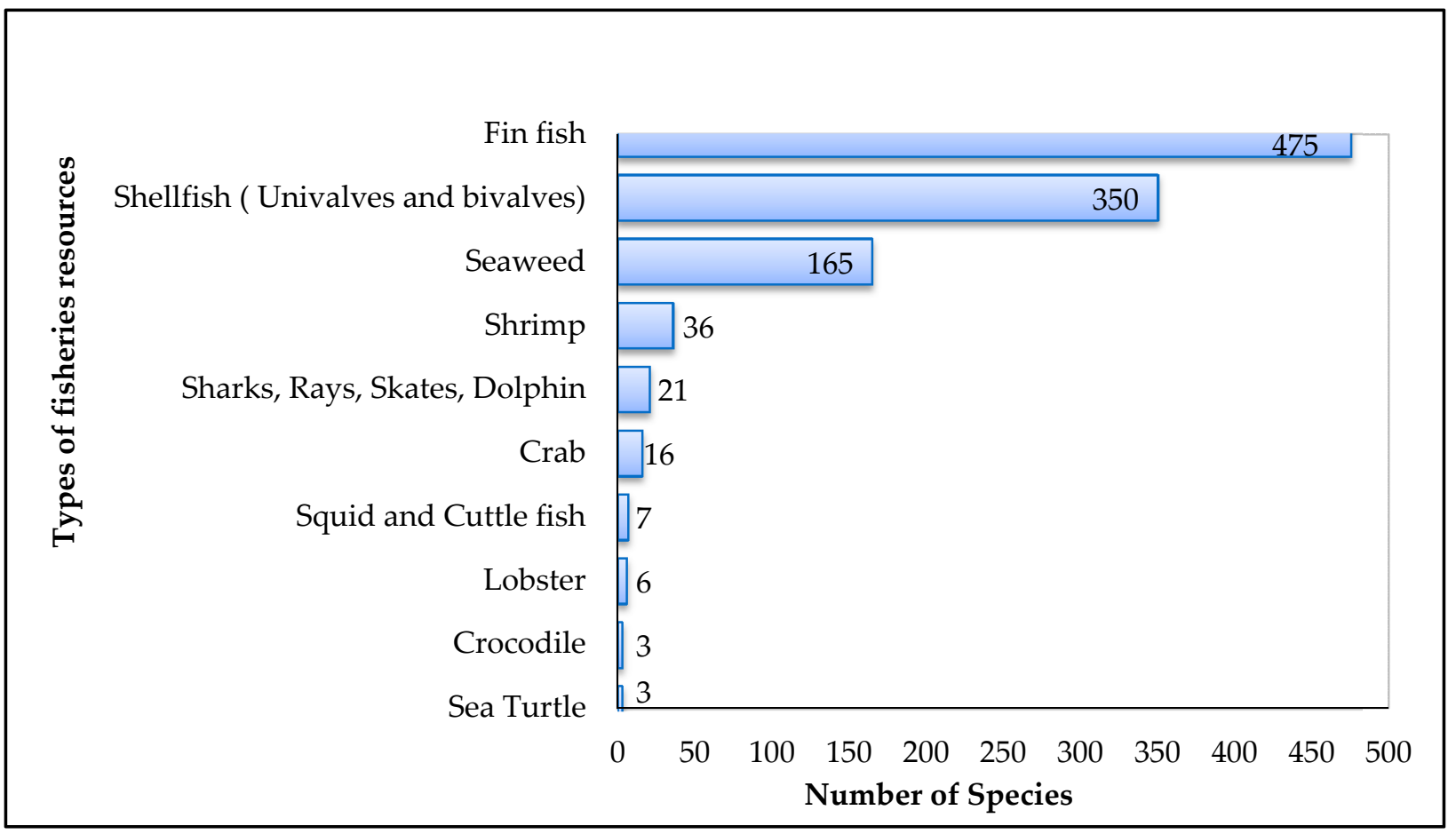

Figure 3. Coastal and marine fisheries resources in Bangladesh [29]. Data source: Food and Agricultural Organization of the United Nations (FAO) [29]. 
Marine fisheries production contributes only $15 \%$ to overall national fish production (Table 1) $[29,30]$. The coastal fisheries resources are over-exploited, and as a result, the fish stocks and other resources have declined. Numerous surveys examined the status of marine fisheries resources between the 1970s and 1980s, but no current or comprehensive knowledge is available on the fisheries stocks, nor the systematic, biological, and ecological aspects of Bangladesh's coastal and marine fisheries [31,32]. The main commercial fishing zones in the Bay of Bengal are Swatch of no Ground, Middle Ground, South Patches and South of South Patches [33,34]. Artisanal or subsistence fishing is conducted near the coastal areas of Bangladesh. Hilsa shad, sardine, Bombay duck, salmon, pomfret, jewfish, sharks, and rays, among others, are the dominant species captured from marine and coastal water areas [7].

Although the production growth rates fluctuate among the sub-sectors of inland fisheries, the total annual production had gradually increased over the past decade (financial years of 2008-2009 to 2018-2019) and developed a solid ground for stable aquaculture and fisheries production (Table 5).

Table 5. Sector-wise annual fish production from financial years of 2008-2009 to 2018-2019 in Bangladesh.

\begin{tabular}{|c|c|c|c|c|c|c|c|c|c|c|c|}
\hline \multirow{2}{*}{ A. Inland Fisheries } & \multicolumn{11}{|c|}{ Year-Wise Fisheries Production (Metric Tonnes) } \\
\hline & 2008-2009 & 2009-2010 & 2010-2011 & 2011-2012 & 2012-2013 & 2013-2014 & 2014-2015 & 2015-2016 & 2016-2017 & 2017-2018 & 2018-2019 \\
\hline \multicolumn{12}{|l|}{ (a) Inland (Capture) } \\
\hline 1. River & 138,160 & 141,148 & 144,566 & 145,613 & 147,264 & 167,373 & 174,878 & 178,458 & 271,639 & 320,598 & 325,478 \\
\hline 2. The Sundarbans & 18,462 & 20,437 & 22,451 & 21,610 & 15,945 & 18,366 & 17,580 & 16,870 & 18,086 & 18,225 & 18,282 \\
\hline 3. Beel & 79,200 & 79,209 & 81,564 & 85,208 & 87,902 & 88,911 & 92,678 & 95,453 & 98,117 & 99,197 & 99,890 \\
\hline 4. Kaptai Lake & 8590 & 7336 & 8980 & 8537 & 9017 & 8179 & 8645 & 9589 & 9982 & 10,152 & 10,578 \\
\hline 5. Floodplains & 843,671 & 781,807 & 797,024 & 696,127 & 701,330 & 712,976 & 730,210 & 747,872 & 765,782 & 768,367 & 781,481 \\
\hline \multicolumn{12}{|l|}{ (b) Inland (culture) } \\
\hline 1. Pond & 912,178 & $1,140,484$ & $1,219,736$ & $1,392,412$ & $1,446,594$ & $1,526,160$ & $1,613,240$ & $1,719,783$ & $1,833,118$ & $1,900,298$ & $1,974,632$ \\
\hline 2. Seasonal culture & 35,842 & 46,902 & 51,230 & 132,163 & 200,833 & 193,303 & 201,280 & 207,658 & 215,547 & 216,353 & 217,340 \\
\hline 3. Baor & 5038 & 8727 & 4864 & 5186 & 6146 & 6514 & 7267 & 7729 & 8002 & 8072 & 10,343 \\
\hline 4. Shrimp & 145,585 & 155,866 & 184,939 & 196,306 & 206,235 & 216,447 & 223,582 & 239,798 & 246,406 & 254,367 & 258,039 \\
\hline 5. Crab & - & - & - & - & - & - & - & 13,160 & 14,421 & 11,787 & 12,084 \\
\hline 6. Pen culture & - & - & - & - & - & 13,054 & 13,070 & 13,364 & 13,368 & 10,285 & 12,361 \\
\hline 7. Cage culture & - & - & - & - & - & 1447 & 1969 & 2062 & 2490 & 4253 & 3802 \\
\hline \multicolumn{12}{|l|}{ B.Marine Fisheries } \\
\hline 1.Marine Industrial & 35,429 & 34,182 & 41,665 & 73,386 & 73,030 & 76,885 & 84,846 & 105,348 & 108,479 & 120,087 & 107,236 \\
\hline 2. Marine Artisanal & 479,215 & 483,100 & 504,668 & 505,234 & 515,958 & 518,500 & 515,000 & 521,180 & 528,997 & 534,600 & 552,675 \\
\hline Total (MT) & $2,701,370$ & $2,899,198$ & $3,061,687$ & $3,261,782$ & $3,410,254$ & $3,548,115$ & $3,684,245$ & $3,878,324$ & $4,134,434$ & $4,276,641$ & $4,384,221$ \\
\hline Growth rate (\%) & 5.39 & 7.32 & 5.6 & 6.54 & 4.55 & 4.04 & 3.84 & 5.27 & 6.6 & 3.44 & 2.52 \\
\hline
\end{tabular}

Data source: Department of Fisheries (DoF) [7].

\section{Fish Production Trends in Bangladesh from 1983-1984 to 2017-2018}

Bangladesh's total inland open water fish production in 2003-2004 was 732,067 MT, which slowly increased and reached 1,235,709 MT in 2018-2019 (Figure 4) [7]. Whereas inland closed water fish production in Bangladesh has doubled in the last decades, inland open water production has been slower to increase. It was reported that the country's total inland closed water fish production was 914,752 MT in 2003-2004 and had become 2,405,415 MT by 2017-2018. The country's total marine water fish production was 455,207 MT in 2003-2004 and had become 654,687 MT by 2017-2018. However, during the last three years, a slight increase in marine water fish production was observed, while it remained more or less constant in 2015-2018. 


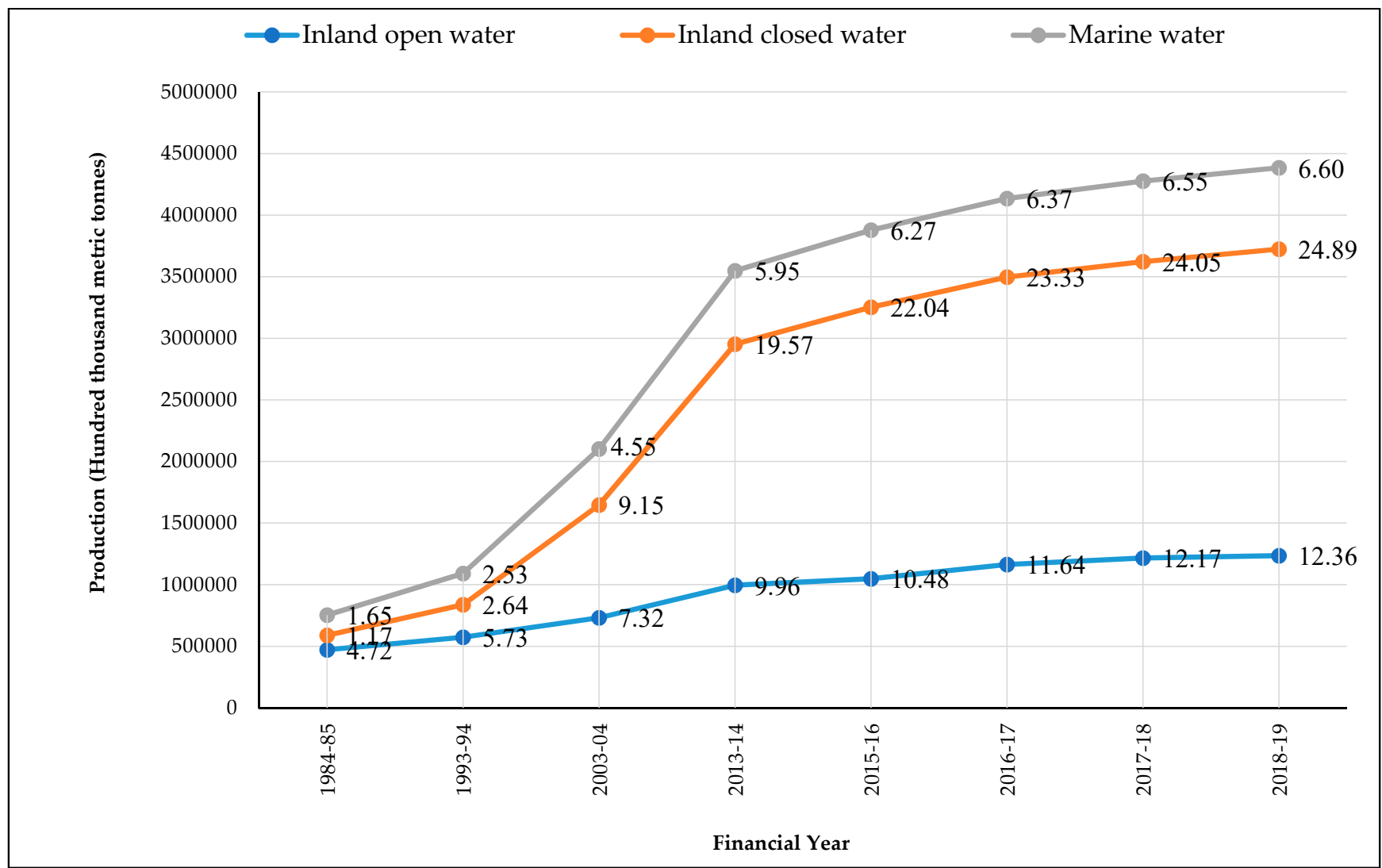

Figure 4. The trend of fish production in Bangladesh (1983-1984 to 2018-2019). Data source: Department of Fisheries (DoF) [7].

\section{Export of Fish and Fishery Products}

The fisheries sector of Bangladesh has emerged as the second most essential contributor to export earnings. Ten categories of fishery products (frozen freshwater fish, frozen marine water fish, frozen shrimp, chilled fish, live fish, dry fish, salted and dehydrated fish, kuchia (Monopterus cuchia) and crab (Scylla sp.) in live condition, and fish scales/shrimp skulls) are exported from Bangladesh to more than 55 countries. The shrimp export destinations are highly concentrated in the European Union (EU). More than $45 \%$ of fishery exports (by quantity) were exported to the EU in 2015. The remaining $55 \%$ were exported to the USA, Japan, Russia, China, Thailand, Vietnam, India, Malaysia, Philippines, and Saudi Arabia $[11,35,36]$. The year-wise annual export value was highest in 2013-2014, but during the last three years (2015-2019), the export value and quantity sharply decreased compared to previous years (Figure 5) [7]. 


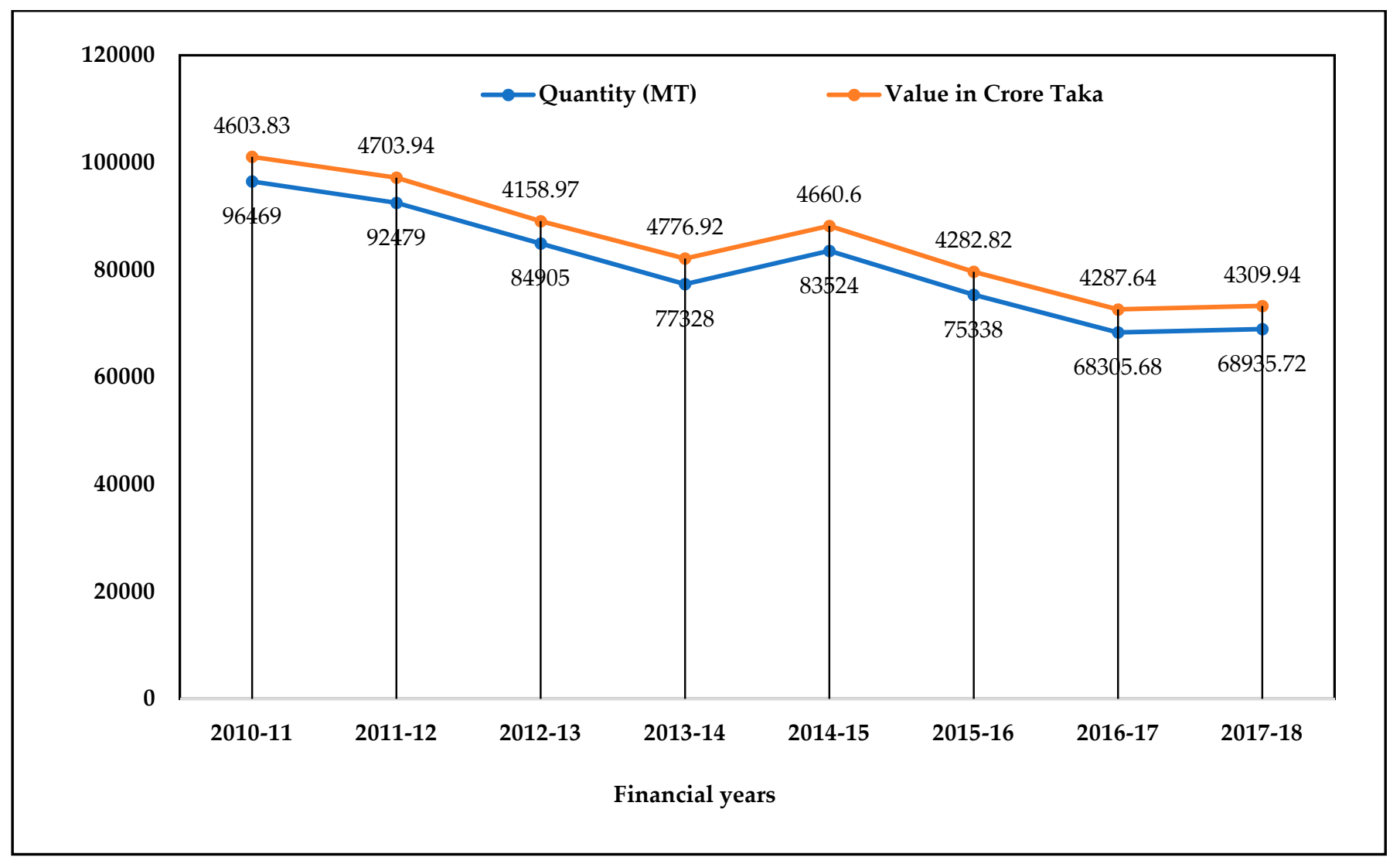

Figure 5. Year-wise annual export value of fish and fisheries product in BDT. Data source: Department of Fisheries (DoF) [7].

\section{Fisher's Livelihood and Vulnerabilities: Observations from Fieldwork}

The research findings showed that most fishers had inadequate income and poor housing facilities, which is concordant with other studies' findings in Bangladesh [37,38]. Fishers were identified as having not received proper institutional education and bearing the responsibilities of large family sizes [39,40]. They, in turn, cannot afford to send their children to school, which is relevant to SDG 4 which addresses access to quality education. However, most fishers reported having sanitary latrine facilities (related to SDG 3: good health and well-being) and using solar power as a primary source of electricity.

The fishers were not concerned about the nutritional value of foods and consumed fish as it was all they could afford fish. Fishers reported a reliance on loans to maintain their family during hard times and for the purchase of fishing equipment (e.g., net, fishing pot, boat, etc.). They faced several constraints, as outlined in Figure 6. The significant constraints included natural calamities, a reduction in fish catches, an unsatisfactory law and order situation, a lack of access to credit, ban periods, environmental degradation in coastal areas, a lack of alternative income-generating activities (IGAs), lack of communitybased organisation, lack of infrastructure, the burden of Dadon (rent money), inadequate market facilities, and the loss of fishing equipment. Dependency on a single livelihood option, namely, fishing, increases their vulnerability. Conflicts between stakeholders, such as boat owners and moneylenders, also hampered financial stability and made illegal fishing an attractive option [41,42]. The livelihood status of the fishing communities was also affected by various types of seasonal stress. The ban period and the seasonal shifts in the fish availability make the fishers more vulnerable. 


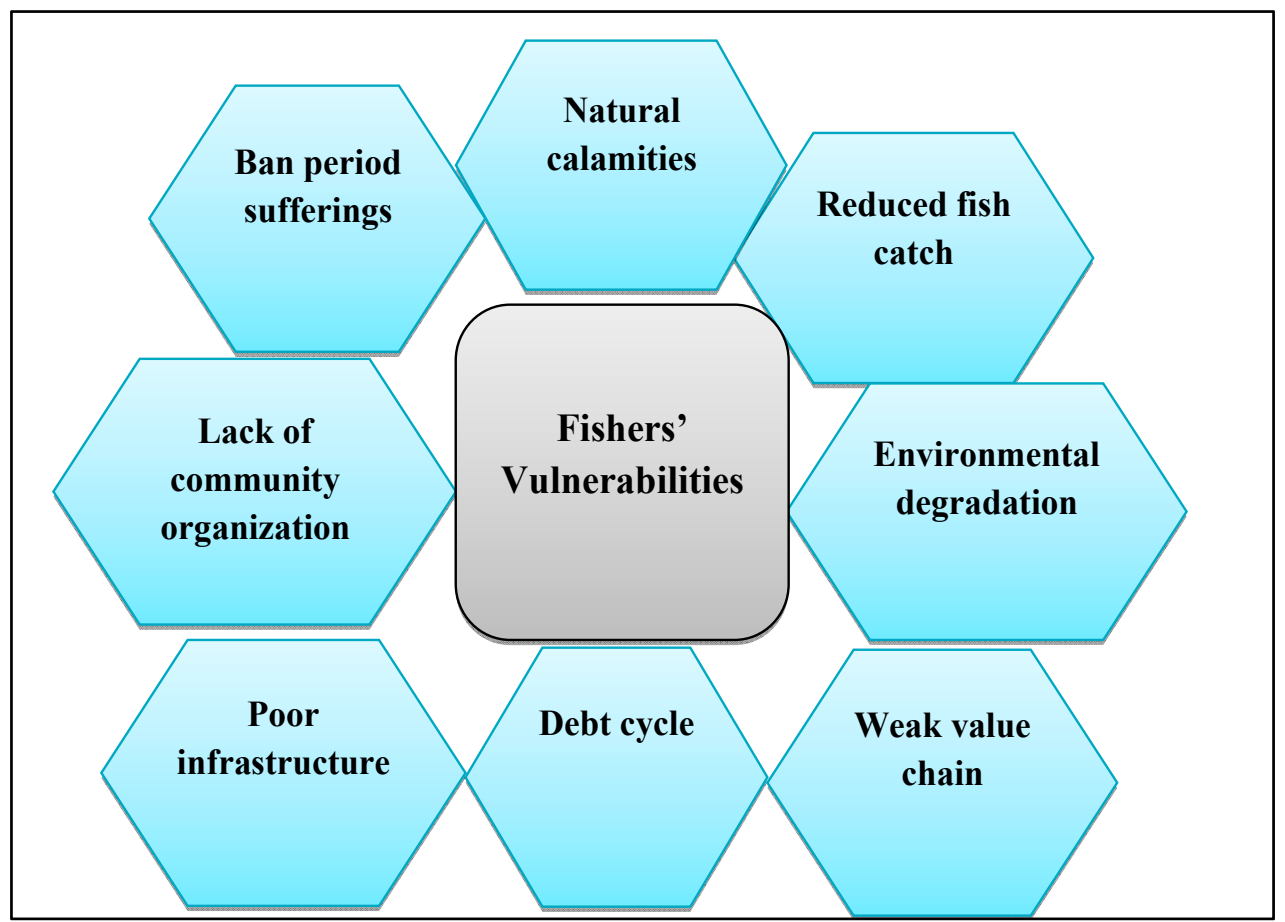

Figure 6. Fishers' vulnerabilities (contextually modified after Sunny et al., 2021 [8]).

Shocks, including natural disasters such as floods, droughts, cyclones, earthquakes, landslides, disease epidemics, and sudden economic changes, affect the livelihood of fishers. In the fishery context, cyclones and floods have a devastating effect on life and property (SDG 13: climate action). Loss of life (loss in human capital), physical infrastructure, and assets, such as the loss of fishing gear, roads, bridges and transport linkages, limit the access to health and education services and employment opportunities in other sectors. Compared with farming communities, coastal fishing communities are more susceptible to inclement weather conditions $[43,44]$.

\section{COVID-19 Scenario and Responses in Bangladesh}

Bangladesh is facing momentous challenges in tackling the COVID-19 pandemic after confirming the first COVID-19 case within its borders on 8 March 2020 and the first death shortly thereafter on 18 March 2020. The media and some academics believe that COVID-19 may have been present in Bangladesh earlier, but not remained unidentified due to insufficient monitoring and inadequate testing [45]. While the number of infected cases remained low until the end of March 2020, in April, the suspected case rate showed a sharp rise with the new suspected rate in Bangladesh reaching $1155 \%$ in mid-April when $186 \%$ was the highest in Asia, placing the country ahead of India, Indonesia, Thailand, and Sri Lanka [8]. On 31 May 2020, a total of 312,061 suspected cases were tested, of which 47,153 cases were confirmed positive; there were also 9781 recovered cases, and the total number of deaths increased to 650 . As time passed, the country experienced an increase of COVID-19 in all divisions. As of 1 August 2021, the highest increase in cases was observed in the Dhaka division (760,062 cases), followed by the Chattogram division (181,832 cases), Khulna division (93,644 cases), Rajshahi division (83,558 cases), Rangpur division (44,875 cases), Sylhet division ( 39,966 cases), Barishal division (33,870 cases), and Mymensingh division (26,521 cases). The number of recovered and death cases has also increased simultaneously (Figure 7). 


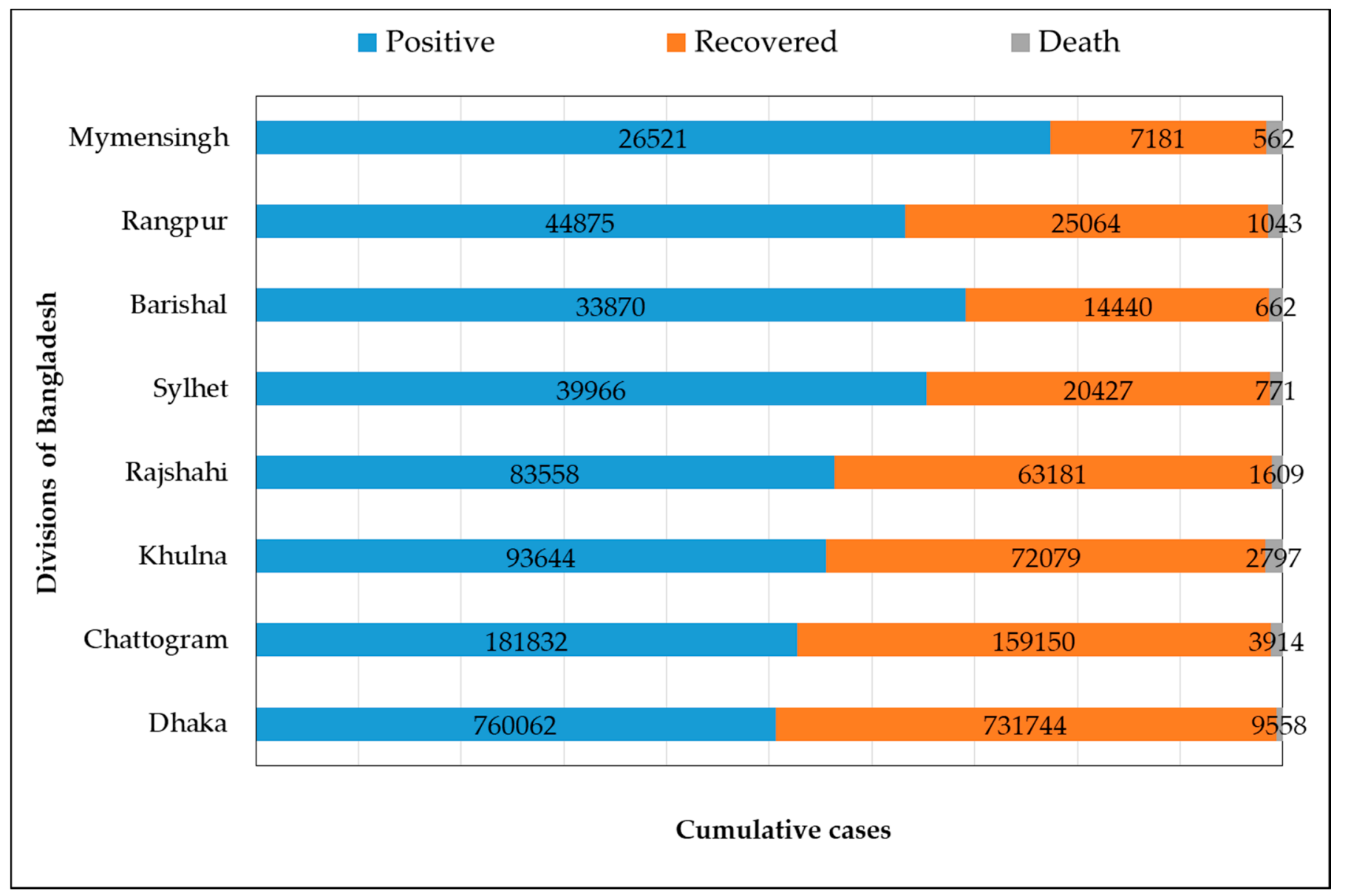

Figure 7. Positive, recovered, and death statistics of COVID-19 in Bangladesh.

In the early stages of COVID-19 in Bangladesh, there were no strict protocols nor lockdowns. To control the transmission of the virus, the Bangladesh government suspended on-arrival flights from all European countries on 14 March 2020, shut down all educational institutions on 17 March 2020, and deployed troops for quarantine supervision on 19 March 2020. The government of Bangladesh declared a ten-day nationwide lockdown for the first time on 23 March 2020, effective from 26 March to 04 April 2020. On 1 June 2020, the restrictions were eased despite the growing number of COVID-19 cases and associated deaths. All offices, shops, and public transportation were restricted, following the strict health guidelines. On 25 October 2020, the Bangladesh government implemented a new policy to wear face masks as "no mask, no service in government and private offices" (Table 6). In the second wave of the coronavirus outbreak in Bangladesh, seven days of controlled movement was imposed all over the country on 5 April 2021. On 14 April 2021, a strict lockdown was imposed until 21 April and later extended to May, closing all government and non-government organisations, except emergency services. The government imposed another lockdown, to control the spread, from 1 July until 07 July, but it was later extended until further notice. 
Table 6. Snapshot of COVID-19 response in Bangladesh.

\begin{tabular}{ll}
\hline & \multicolumn{1}{c}{ COVID-19 Response } \\
\hline 8 March 2020 & First COVID cases identified \\
14 March 2020 & Shut down of all educational institution \\
15 March 2020 & Banned flights from Europe \\
18 March 2020 & First death and banning of all types of gatherings \\
26 March 2020 & Nationwide lockdown declared \\
1 June 2020 & Eased restrictions despite ongoing pandemic \\
25 October 2020 & Implemented "no mask, no service" policy \\
19 December 2020 & Closure of educational institutions extended \\
5 April 2021 & Imposed seven days-controlled movement \\
14 April 2021 & Strict lockdown imposed \\
1 June 2021 & Eased restrictions despite ongoing pandemic \\
1 July 2021 & Strict shutdown imposed \\
\hline
\end{tabular}

\section{Impact of COVID-19 on Bangladesh Fisheries}

This section presents the quantitative and qualitative findings to identify the impact of the COVID-19 pandemic on the fisheries sector.

\subsection{Perceived Impacts of COVID-19 on the Fisheries Sectors}

The COVID-19 pandemic has seriously hampered fishing, fish farming, and fish marketing activities and impacted the livelihood of fishery-depended communities. Respondent perceptions of the COVID-19 impact on the fisheries sector were explored through seven statements with five-point Likert scales (Table 7). Participants strongly believed that the pandemic negatively impacted fish production, fishing activities, household food consumption, and income. Some perceived the pandemic to be associated with increased conflicts and stress.

Table 7. Perceptions of the respondents on the influence of COVID-19 on the fisheries sector of Bangladesh.

\begin{tabular}{cccccc}
\hline Questions Related to Impact & \multicolumn{3}{c}{ Responses (\%) } \\
\cline { 2 - 6 } COVID-19: COVID-19 Has & Strongly Agree & Agree & $\begin{array}{c}\text { Neither Agree } \\
\text { nor Disagree }\end{array}$ & Disagree & Strongly Disagree \\
\hline Negatively influenced fish & 59.00 & 22.00 & 19.00 & 0.00 & 0.00 \\
production & 55.70 & 33.30 & 7.70 & 0.00 & 0.00 \\
Negatively influenced fishing & 27.90 & 47.20 & 15.40 & 5.20 & 4.30 \\
Negatively impacted household & 59.80 & 25.90 & 14.30 & 0.00 & 0.0 \\
food consumption & 3.50 & 21.50 & 40.90 & 24.10 & 10.00 \\
Negatively influenced income & 0.00 & 11.00 & 51.00 & 23.00 & 15.00 \\
Increased conflicts & 2.90 & 9.10 & 45.20 & 32.80 & 10.00 \\
Increased hygiene practice & & & & \\
Increased stress & & Data & & & \\
\hline
\end{tabular}

Data source: Field survey, 2021.

\subsubsection{Markets}

COVID-19 has drastically transformed Bangladesh's fish markets, homestead, and commercial aquatic food production system (SDG 12: responsible production and consumption). Usually, marginalised fish farmers cultured fish to meet their nutritional demands and sold any remaining fish to supplement their family income. COVID-19 impacted the supply of farming inputs and restricted farmers to the home, which decreased business profitability. During the first weeks of lockdown, the fish prices fell in alignment with the reduced demand, despite fish being the most consumed animal-source food in Bangladesh (SDG 14: life below water). Fish farmers and vendors reported transportation of fish, fingerlings, feed, and other inputs as a main problem, and more than $58 \%$ of fish farmers indicated that they could not sell their marketable fish due to transportation complexity 
and low market demand. As a result, a good portion of mature fish remained unsold, with farmers spending extra money to feed them, which ultimately increased expenditures and reduced the family income (SDG 12: responsible production and consumption). Generally, low-income workers are the primary consumers of pangus (Pangasianodon hypophthalmus) and tilapia (O. niloticus), which are produced inexpensively all over the country. Nevertheless, at the start of COVID-19, millions of workers migrated back to their hometowns, thereby reducing demand, and the price of pangus in the retail markets decreased from BDT $120 / \mathrm{kg}$ to BDT $60 / \mathrm{kg}$.

COVID-19 also affected the livelihood of crab farmers and traders as exports were indefinitely postponed. With China as the primary export market for crabs, and due to an import ban on 25 January, the export market of crabs remains closed. According to the Rampal-Bagerhat Crab Dealers Association, the main import target is the Chinese New Year festival, which was hindered due to the export ban with many crabs dying as a result of COVID-19 restrictions [45-48]. Though COVID-19 restrictions reduced the export opportunities, however, they opened the door to local markets and increased the access to fishery items. During the COVID-19 pandemic, local people were able to access fishery items that were previously relegated to the seafood processing industry and considered export items. The increased supply of fish in the local market reduced its price and the income of fishers.

\subsubsection{Fishers}

In Bangladesh, April and May are the best time to release fry into farming ponds, and between March and April, fish farmers prepare the pond for the new season by selling the mature fish from the previous year. About $39 \%$ of the fish farmers and vendors claimed that they could not start a new farming cycle due to unsold mature fish (SDG 12: responsible production and consumption). It also affected the supply chain, as the local vehicles, such as trucks, pickups, and vans, were hesitant to transport fish fingerlings, feed, and other materials; because of the lockdown, transporters often face various obstacles and fines that adversely impact the fish landing centre, wholesale, and retail market. During the early phases of the pandemic, very little fishing is thought to have taken place even though no regulations were preventing it. Fishers were compelled to stay at home and were hesitant to fish when the demand for fish was decreasing [45]. Many fishers and entrepreneurs lost their income at the beginning of the crisis when they could not arrange transport for their most recent catch.

March to April was also the seasonal hilsa conservation ban period, which affects the fishing communities in the major rivers of Bangladesh. During the ban period, a restriction is imposed in all hilsa sanctuaries, and, with the seasonal ban period, the lack of alternative sources of income increased the vulnerability of these communities in addition to the COVID-19 crisis. The government-provided-subsidisation was far less than what was required for the fishers to maintain their wellbeing (SDG 1: no poverty). It was also reported that many fishers were unable to receive this support due to nepotism $[8,49,50]$.

\subsubsection{Fish Farmers}

In Bangladesh, March and April are the peak season for fish stocking, which coincided with the beginning of the COVID-19 crisis that began in March 2020, just before peak harvest season. As the prices and demand for fish were decreasing gradually and transportation systems broke down, most farmers decided to retain their fish in their ponds instead of harvesting them (SDG 12: responsible production and consumption). One interviewee predicted that the price of fish might remain low even after the pandemic when other farmers also begin harvesting fish, and that the surplus supply will depress prices further.

Traders usually pay fish farmers after the fish are sold. With COVID-19, farmers fear losing their income if the traders are unable to sell the fish, while unsold fish cannot be returned due to transport disruptions and a lack of storage options. Due to the delayed harvesting of mature fish, the fry cannot be stocked at the onset of the monsoon (the start 
of the primary growing season), which may reduce the supply of fish in the first half of 2021 [8].

\subsubsection{Seed}

In Bangladesh, the COVID-19 crisis started in March 2020; March is the peak season for hatchery owners to sell their fish seeds and ready themselves for a new production cycle. The demand for fish seed fell dramatically due to farmers' uncertainty and the inability to harvest (SDG 12: responsible production and consumption). In some hatcheries, due to the lack of separate nursing ponds, they were unable to store seed five to seven days more. One of the hatchery specialists from the Jessore district reported that, while the hatchery had remained closed, they had to pay the hatchery staff. Another hatchery manager from Mymensing informed us that, due to COVID-19, they had to sell their seed at a low price, and that most hatcheries and farmers doubted whether they would get their production cost or not. Hatchery owners from Northwest Bangladesh were reported to have reduced production by at least $30-40 \%$, and four out of twenty-one have shut down completely. Credit facilities for supplying fry to farmers are no longer possible as nurseries face a liquidity crisis due to a lack of sales. Hatchery inputs, such as pituitary glands, hormones, and probiotics, are imported from outside Bangladesh. Due to lockdown, the inputs import has become more challenging. The price of the pituitary gland has tripled since the crisis started. Due to the COVID- 19 lockdown, transporting hatchery inputs and fry is a crucial challenge faced by fish hatcheries, nurseries, and fish farmers [51].

\subsubsection{Feed}

Most of the feed mills import their ingredients to produce feed. Due to the COVID-19 situation, importing goods has become more challenging as a result of the price hike and transportation complexity. Experts predicted a $42 \%$ reduction in feed supply due to input shortages and low demand. As the feed production costs increased, this led to speculation on whether millers will compromise the feed quality. Commercial small-scale producers are concerned about feed access.

\section{Prospects, Development-Relevance and Linkage of Fisheries and Aquaculture Sectors in Achieving SDGs in Bangladesh}

Bangladesh achieved a prestigious global position due to its outstanding production of inland open water capture fisheries (third) and culture fisheries (fifth) [7]. Globally, $60 \%$ of total hilsa (Tenualosa ilisha) production is from Bangladesh [8]. The fisheries and aquaculture sectors are inextricably linked to achieving several SDGs and have development relevance (e.g., economic, social, and environmental) in Bangladesh. Among the 17 SDGs, these sectors directly or indirectly contribute to achieving several SDGs, such as eliminating poverty (SDG 1), reducing hunger (SDG 2), promoting good health and well-being (SDG 3), establishing decent work and economic growth (SDG 8), influencing responsible consumption and production (SDG 12), organising climate action (SDG 13), developing life below water (SDG 14), and advancing life on land or life above water (SDG 15) (Table 8).

\subsection{Prospects of Inland Closed Water}

Inland closed water fish production is almost saturated, but a five-fold increase in production will be needed within the next five decades to maintain current levels of aquatic food intake (SDG 12: responsible production and consumption). Bangladesh has advanced technology, such as RAS (re-circulatory aquaculture system), biofloc, and aquaponics [2]. These technologies are considered eco-friendly alternatives of fish culture, a less diseaseprone system, which enhances productivity and, consequently, sustainable production. 
Table 8. Prospective linkage of fisheries and aquaculture sectors with achieving the SDGs in the context of Bangladesh.

\begin{tabular}{|c|c|c|c|c|}
\hline \multirow{2}{*}{$\begin{array}{c}\text { The United Nations } \\
\text { Sustainable Development } \\
\text { Goals SDGs (1-17) }\end{array}$} & \multicolumn{3}{|c|}{ Direct or Indirect Linkage with Fisheries and Aquaculture Sub-Sectors } & \multirow{2}{*}{$\begin{array}{c}\text { Linked with the } \\
\text { Dimensions of Sustainable } \\
\text { Development }\end{array}$} \\
\hline & Inland Closed Water (Culture) & Inland Open Water (Capture) & Marine Water (Capture) & \\
\hline Eliminate poverty & High & High & Medium & 1,2 \\
\hline Erase hunger & High & High & High & 1,2 \\
\hline $\begin{array}{l}\text { Establish good health and } \\
\text { promote well-being }\end{array}$ & High & Medium & Medium & 1,2 \\
\hline $\begin{array}{l}\text { Provide inclusive and } \\
\text { equitable quality education }\end{array}$ & Low & Low & Low & 1,2 \\
\hline $\begin{array}{l}\text { Gender equality and women } \\
\text { empowerment }\end{array}$ & Low & Low & Low & 2 \\
\hline $\begin{array}{c}\text { Ensure clean water and } \\
\text { sanitation }\end{array}$ & Low & Low & Low & 3 \\
\hline $\begin{array}{l}\text { Affordable, reliable, and } \\
\text { modern clean energy }\end{array}$ & Low & Low & Low & 3 \\
\hline $\begin{array}{l}\text { Create decent work and } \\
\text { promote economic growth }\end{array}$ & Medium & Medium & Low & 1,2 \\
\hline $\begin{array}{l}\text { Increase industry, } \\
\text { innovation, and } \\
\text { infrastructure }\end{array}$ & Medium & Medium & Medium & 1,3 \\
\hline $\begin{array}{l}\text { Influence reduction of } \\
\text { inequalities }\end{array}$ & Low & Low & Low & 2 \\
\hline $\begin{array}{l}\text { Mobilise sustainable cities } \\
\text { and communities }\end{array}$ & Low & Low & Low & 2 \\
\hline $\begin{array}{l}\text { Ensure responsible } \\
\text { consumption and } \\
\text { production }\end{array}$ & High & High & High & 1,2 \\
\hline $\begin{array}{l}\text { Climate action to combat } \\
\text { climate change impacts }\end{array}$ & Low & Low & Low & 3 \\
\hline $\begin{array}{l}\text { Develop life below water or } \\
\text { conserve and sustainable } \\
\text { resource utilisation }\end{array}$ & Very high & Very high & Very high & $1,2,3$ \\
\hline $\begin{array}{l}\text { Advance life above water or } \\
\text { life on land }\end{array}$ & Low & Low & Low & 3 \\
\hline $\begin{array}{l}\text { Assurance peace, justice, } \\
\text { and strong institutions }\end{array}$ & Low & Low & Low & 2 \\
\hline $\begin{array}{l}\text { Build and strengthen global } \\
\text { partnerships for the } \\
\text { sustainable development }\end{array}$ & Low & Low & Low & 1,2 \\
\hline
\end{tabular}

Criteria and scores are based on the authors' critical qualitative evaluations of field observations and experiences. Low (too little, scant or negligible linkage, score: 0-25); Medium (moderate or mild linkage exists but not well-defined, score: 26-50); High (good linkage, nevertheless, still needs to be defined clearly, score: 51-75); Very high (direct linkage with clear definition, score: 76-100) The idea of contextualising and generating this table benefited from Wang et al. (2020) and de Bisthoven et al. (2020) [52,53]). Potentially linked with dimensions of sustainable development indicates: (1) economic growth, (2) social inclusion, and (3) environmental protection.

\subsection{Prospects of Inland Open Water}

Although Bangladesh is blessed with substantial open water resources (SDG 14: life below water), only $28 \%$ of fish production derives from closed inland waters. Increasing production requires the promotion of the pen and cage culture system. It is estimated that only 1.29 lakh $\mathrm{m}^{3}$ and 5294 ha are under the cage and pen culture system. For example, the community-based fisheries management, i.e., the Daudkandi model of community floodplain aquaculture [54,55], is expected to improve fisher access, livelihoods, and the sustainability of the fisheries sector. Co-management of natural wetlands could be another option to protect and increase the biodiversity and livelihood of the dependent community [9].

\subsection{Prospects of Marine Fisheries Resources}

The utilisation of marine resources by implementing proper management strategies is essential to meet SDG 14 (life below water). Following prospects will open the door for establishing a special economic zone to develop the southern part of Bangladesh.

\subsubsection{Blue Economy}

The blue economy is an emerging concept in Bangladesh, which refers to the ocean, seas, and coast $[56,57]$. Ocean resources are a potential resource for increasing food security, improving nutrition and health, alleviating poverty, creating jobs, generating alternative energy, seaborne trade, and industrial profiles (SDG 1: no poverty; SDG 2: zero hunger; SDG 3: good health and well-being; SDG 10: reduced inequalities) [58,59]. According to 
expert opinion, Bangladesh would extract about USD 1.2 billion from its substantial marine resources [60,61]. It will be a stepping stone to meet the Vision-2041 of Bangladesh if the resources are sustainably extracted and adequately used. It is possible to achieve $5 \%$ of the GDP by 2030 through the utilisation of sea resources.

\subsubsection{Biotechnology and Marine Genetic Resource}

Marine biotechnology can address several global challenges, including, but not limited to, human health, sustainable food supplies, environmental remediation, and energy security [62]. Many marine resources are a significant source of potential drugs, particularly antibiotics. For example, in 2017, there were over 36 marine-derived drugs in clinical development, including 15 to treat cancer [63,64].

\subsubsection{Research}

Research works related to marine fisheries resources and their production performance are very limited in Bangladesh. Therefore, appropriate research works on marine fisheries are required. Several marine fishery academies and institutes are available in Bangladesh, which can significantly increase marine fisheries production.

\section{Challenges of Fisheries and COVID-19 Nexus to Achieve SGDs and Recovery Plans}

Short-term and long-term recovery plans can potentially tackle the COVID-19 crisis in terms of addressing the immediate need and durable requirements for the sustainable recovery of the fisheries sector. Some recovery plans elicited from community perception and the authors' suggestions are discussed below.

\subsection{Need for Emergency Financial and Non-Financial Support}

The overall income of fish farmers, fishers, and relevant stakeholders was severely affected, influencing the violation of fisheries rules. Immediate financial support, such as a rationing system as well as psychological counselling, could be effective. An urgent management strategy needs to be developed and implemented to save the livelihoods of fishers, hatcheries, feed industries, and other stakeholders [53].

\subsection{Building Resilient Fisheries and Aquaculture Sector}

During the COVID-19 lockdown and imposed restrictions, many fishers and fish labourers lost their income. In order to make the fisheries and aquaculture sector resilient, emphasis should be given to increase the capacity of the stakeholders by providing subsidies, incentives, interest-free loans, and alternating income-generating options.

\subsection{Addressing Potential Threats in Aquatic Biodiversity}

The degradation of aquatic biodiversity is one of the primary concerns in Bangladesh. IUCN assessments show that 64 out of 253 fish species are threatened, 9 are critically endangered, 30 are endangered, and 25 are vulnerable [56,65]. Excessive use of surgical face masks, disinfectants, hand sanitiser, and other pharmaceutical chemicals may also induce threats and water pollution. The return of the unemployed in the fishing sectors may increase overfishing and impose threats to biodiversity. A comprehensive management strategy including, but are not limited to, an awareness program is required for biodiversity conservation and COVID-19 risk mitigation.

\subsection{Integrating Climate Change Risks with the Responses of COVID-19}

Bangladesh is highly sensitive to climate change due to its geography, and experiences frequent floods and cyclones (SDG 13: climate action) [66,67]. The current pandemic affects the coping strategy of fishers and the domestic food supply $[24,48,49]$. Developing appropriate technology and management strategies for resilient inland and marine fisheries is a mandate for Bangladesh, integrating climate change and COVID-19. 


\subsection{Initiatives to Address the Risk of Orders Cancellation by Foreign Buyers}

During the lockdown, foreign shellfish buyers cancelled their orders due to border travel restrictions, which was an alarming issue for the shrimp industry. Minimising the risk of such cancellations requires more initiatives by fisheries and transport sectors for the smooth and safe transport of fish products.

\subsection{Developing Long-Term Strategies}

A long-term management strategy is essential for the sustainable development of the fisheries sector and for tackling the COVID-19 pandemic threats. The human resources and budget allocation $(0.56 \%$ of the national budget) for the fisheries sector should be increased. A package of development and extension projects need to be implemented at the marginal level to provide financial, technical, and moral support to the fish farmers and fishers.

\section{Conclusions and Recommendations}

Fisheries are crucial in the national macroeconomic, food and nutrition security perspectives (SDG 1: no poverty; SDG 2: zero hunger; SDG 14: life below water). The COVID-19 pandemic adversely affected the fisheries and aquaculture sectors in many ways. Therefore, efficient and sustainable management of aquatic resources is essential for the continued and significant contribution to the country's health and economic sector. Despite the enormous prospects and potential, several reasons, such as climate change, onshore coal-based power plant installation, a lack of scientific information, skilled human resources, and poor implementation of acts and rules related to marine fisheries, limit the fisheries resources, production, and performance. However, the supply of good quality seed, feed, and extension services could increase fisheries production in inland water bodies. To have a resilient coastal and marine aquaculture development, adopting appropriate technology is a prerequisite for Bangladesh. The development of communication and transportation systems for rapid access to information, coordination with the regional and international networks for updated technology, value chain, and proper utilisation of the marine resources is required to boost the total fisheries production of Bangladesh.

Policymakers should be more aware of their well-planned efforts to meet the SDGs that can also ensure precise and prompt functioning of the fisheries sector. Interdisciplinary coordination for enhancing investment, research infrastructure, environmental policies, and the introduction of modern storage and marketing facilities could rapidly improve the situation. Perceptions of small-scale fishers should be considered during the policymaking process. Particular strategies and emphasis are required to assess their vulnerability and sustainability. Attention should also be paid to the environmental abnormalities and constraints, such as frequent climatic disasters (SDG 13: climate action), a declining aquatic biodiversity trend (SDG 14: life below water), and increased water and air pollution trends, in connection with the success of the fisheries sector.

Author Contributions: A.R.S.: conceptualization, designed and performed research, methodology validation, field works, data curation, data analysis, writing the original draft, reviewing, and editing; M.H.M., S.H.P., and M.A.: designed research, methodology validation, formal analysis, data curation, data analysis, visualization, reviewing, and editing; S.M.A.R., M.M.B., M.H., K.J.A., S.A.S., M.T.A. and A.R.: methodology validation, formal analysis, investigation, visualization, reviewing, editing, and proof reading, M.M.H.: conceptualization, designed research, methodology validation, formal analysis, investigation, visualization, reviewing, and editing. All authors have read and agreed to the published version of the manuscript.

Funding: This research received no external funding.

Institutional Review Board Statement: Not applicable.

Informed Consent Statement: Written informed consent was obtained from the participants.

Data Availability Statement: Not applicable. 
Acknowledgments: We would like to thank the editor of Sustainability and the anonymous reviewers for their comments and suggestions, which helped improve the paper. We would like to express our deepest gratitude to the respondents who provided valuable information. Thanks to Md. Abdul Baten for helping to prepare Figure 1. We acknowledge the logistic and technical support of the Department of Genetic Engineering and Biotechnology of Shahjalal University of Science and Technology, Sylhet, Bangladesh.

Conflicts of Interest: The authors declare no conflict of interest.

\section{References}

1. Kuddus, M.A.; Datta, G.C.; Miah, M.A.; Sarker, A.K.; Hamid, S.M.A.; Sunny, A.R. Performance Study of selected Orange Fleshed Sweet Potato Varieties in North Eastern Bangladesh. Int. J. Environ. Agric. Biotechnol. 2020, 5, 673-682. [CrossRef]

2. Ghose, B. Fisheries and Aquaculture in Bangladesh: Challenges and Opportunities. Ann. Aquac. Res. 2014, 1, 1-5.

3. Shamsuzzaman, M.M.; Islam, M.M.; Tania, N.J.; Al-mamun, M.A.; Barman, P.P.; Xu, X. Fisheries resources of Bangladesh: Present status and future direction. Aquac. Fish. 2017, 2, 145-156. [CrossRef]

4. Sunny, A.R.; Masum, K.M.; Islam, N.; Rahman, M.; Rahman, A.; Islam, J.; Rahman, S.; Ahmed, K.J.; Prodhan, S.H. Analysing livelihood sustainability of climate-vulnerable fishers: Insight from Bangladesh. J. Aquac. Res. Dev. 2020, 11, 593. [CrossRef]

5. Islam, M.R.; Cansse, T.; Islam, M.S.; Sunny, A.R. Climate change and its impacts: The case of coastal fishing communities of the Meghna river in south central Bangladesh. Int. J. Mar. Environ. Sci. 2018, 12, 368-376. [CrossRef]

6. Islam, M.M.; Sunny, A.R.; Hossain, M.M.; Friess, D. Drivers of Mangrove Ecosystem Service Change in the Sundarbans of Bangladesh. Singap. J. Trop. Geogr. 2018, 39, 244-265. [CrossRef]

7. DoF. Yearbook of Fisheries Statistics of Bangladesh, 2018-2019; Fisheries Resources Survey System (FRSS), Department of Fisheries: Dhaka, Bangladesh, 2019; pp. 35-38.

8. Sunny, A.R.; Sazzad, S.A.; Prodhan, S.H.; Ashrafuzzaman, M.; Datta, G.C.; Sarker, A.K.; Rahman, M.; Mithun, M.H. Assessing impacts of COVID-19 on aquatic food system and small-scale fisheries in Bangladesh. Mar. Policy 2021, 126, 104422. [CrossRef] [PubMed]

9. Sunny, A.R.; Hassan, M.N.; Mahashin, M.; Nahiduzzaman, M. Present status of hilsa shad (Tenualosa ilisha) in Bangladesh: A review. J. Entomol. Zool. Stud. 2017, 5, 2099-2105.

10. Islam, M.M.; Islam, N.; Mostafiz, M.; Sunny, A.R.; Keus, H.J.; Karim, M.; Hossain MZ\& Sarker, S. Balancing between livelihood and biodiversity conservation: A model study on gear selectivity for harvesting small indigenous fishes in southern Bangladesh. Zool. Ecol. 2018, 28, 86-93. [CrossRef]

11. DoF. Yearbook of Fisheries Statistics of Bangladesh, 2017-2018; Fisheries Resources Survey System (FRSS), Department of Fisheries: Dhaka, Bangladesh, 2018; Volume 35, p. 129.

12. Hussain, M.G.; Hoq, M.E. Sustainable Management of Fisheries Resources of the Bay of Bengal; Support to Sustainable Management of the BOBLME Project; Bangladesh Fisheries Research Institute: Mymensingh, Bangladesh, 2010.

13. DoF. National Fish Week, Compendium; Department of Fisheries, Ministry of Fisheries and Livestock, Government of Bangladesh: Dhaka, Bangladesh, 2001. (In Bengali)

14. Hossain, M.A.R.; Wahab, M.A.; Belton, B. The Checklist of the Riverine Fishes of Bangladesh; Fisheries and Aquaculture News (FAN Bangladesh): Dhaka, Bangladesh, 2012; pp. 18-27.

15. Rahman, A.K.A. Freshwater Fishes of Bangladesh; Zoological Society of Bangladesh: Dhaka, Bangladesh, 1989.

16. Felts, R.A.; Rajts, F.; Akhteruzzaman, M. Small Indigenous Fish Species Culture in Bangladesh; IFADEP Sub-Project-2, Development of Inland Fisheries, Integrated Food Assisted Development Project; BdFISH Feature: Dhaka, Bangladesh, 1996.

17. Hossain, M.A.R. An overview of fisheries sector of Bangladesh. Res. Agric. Livest. Fish. 2014, 1, 109-126. [CrossRef]

18. Sunny, A.R.; Reza, J.; Anas, M.; Hassan, M.N.; Baten, M.A.; Hasan, R.; Monwar, M.M.; Solaimoan, H.; Hossain, M.M. Biodiversity assemblages and conservation necessities of ecologically sensitive natural wetlands of north eastern Bangladesh. Indian J. Geo-Mar. Sci. 2020, 49, 135-148.

19. Beveridge, M.C.M.; Little, D.C. The history of aquaculture in traditional societies. In Ecological Aquaculture: The Evolution of the Blue Revolution; Costa-Pierce, B.A., Ed.; Blackwell Science Limited: Oxford, UK, 2002.

20. General Economics Division, Bangladesh Planning Commission. Fisheries Sub-Sector, Seventh Five-Year Plan (FY 2016-FY 2020); Government of People's Republic of Bangladesh: Dhaka, Bangladesh, 2015; pp. 283-291.

21. Azim, M.E.; Wahab, M.A.; Verdegem, M.C.J. Status of aquaculture and fisheries in Bangladesh. World Aquac. 2002, 67, 37-41.

22. Mazid, M.A.; Gupta, M.V. Research and information needs for fisheries development and management. In Proceedings of the National Workshop on Fisheries Resources Development and Management in Bangladesh, Dhaka, Bangladesh, 29 October-1 November 1995.

23. Chakma, S.; Paul, A.K.; Rahman, M.A.; Mithun, M.H.; Sunny, A.R. Impact of Climate Change and Ongoing Adaptation Measures in the Bangladesh Sundarbans. Preprints 2021. [CrossRef]

24. Sunny, A.R. Impact of oil Spill in the Bangladesh Sundarbans. Int. J. Fish. Aquat. Stud. 2017, 5, 365-368.

25. Hossain, M.S. Biological aspects of the coastal and marine environment of Bangladesh. Ocean. Coast. Manag. 2001, 44, 261-282. [CrossRef] 
26. Islam, M.S. Perspectives of the coastal and marine fisheries of the Bay of Bengal, Bangladesh. Ocean. Coast. Manag. 2003, 46, 763-796. [CrossRef]

27. MoFA. Ministry of Foreign Affairs, Press Release: Press Statement of the Hon'ble Foreign Minister on the Verdict of the Arbitral Tribunal/PCA. Dhaka. 8 July 2014. Available online: http:/ / www.mofa.gov.bd/PressRelease/PRDetails.php (accessed on 17 July 2016).

28. Islam, M.M.; Shamsuzzaman, M.M.; Mozumder, M.M.H.; Xiangmin, X.; Ming, Y.; Jewel, M.A.S. Exploitation and conservation of coastal and marine fisheries in Bangladesh: Do the fishery laws matter? Marine Policy 2017, 76, 143-151. [CrossRef]

29. Food and Agricultural Organization. The State of World Fisheries and Aquaculture 2020. Sustainability in Action; FAO: Rome, Italy, 2020. [CrossRef]

30. FRSS. Fisheries Resources Survey System (FRSS), Fisheries Statistical Report of Bangladesh; Department of Fisheries: Dhaka, Bangladesh, 2018; Volume 34, pp. 1-57.

31. Food and Agricultural Organization. The State of World Fisheries and Aquaculture (Opportunities and Challenges); FAO: Rome, Italy, 2014.

32. Khan, M.I.; Islam, M.M.; Kundu, G.K.; Akter, M.S. Understanding the Livelihood Characteristics of the Migratory and NonMigratory Fishers of the Padma River, Bangladesh. J. Sci. Res. 2018, 10, 261-273. [CrossRef]

33. Sunny, A.R.; Ahamed, G.S.; Mithun, M.H.; Islam, M.A.; Das, B.; Rahman, A.; Rahman, M.T.; Hasan, M.N.; Chowdhury, M.A. Livelihood Status of The Hilsa (Tenualosa ilisha) Fishers: The Case of Coastal Fishing Community of The Padma River, Bangladesh. J. Coast. Zone Manag. 2019, 22, 469.

34. Alok, K.P.; Shapon, K.B.; Mohammad, S.I.; Hussain, M.A. Comparative socioeconomic study with a review on fisherman's livelihood around Tulsiganga River, Joypurhat, Bangladesh. J. Fish. Aquat. Sci. 2018, 13, 29-38. [CrossRef]

35. Rana, M.E.U.; Salam, A.; Shahriar, N.K.M.; Hasan, M. Hilsa Fishers of Ramgati, Lakshmipur, Bangladesh: An Overview of SocioEconomic and Livelihood Context. J. Aquac. Res. Dev. 2018, 9, 541.

36. Islam, M.M.; Islam, N.; Sunny, A.R.; Jentoft, S.; Ullah, M.H.; Sharifuzzaman, S.M. Fishers' perceptions of the performance of hilsa shad (Tenualosailisha) sanctuaries in Bangladesh. Ocean. Coast. Manag. 2016, 130, 309-316. [CrossRef]

37. Islam, M.M.; Shamsuzzaman, M.M.; Sunny, A.R.; Islam, N. Understanding fishery conflicts in the hilsa sanctuaries of Bangladesh. In Inter-Sectoral Governance of Inland Fisheries; Song, A.M., Bower, S.D., Onyango, P., Cooke, S.J., Chuenpagdee, R., Eds.; Too Big to Ignore: St. John's, NL, Canada, 2017; pp. 18-31.

38. Haque, N.; Blowfield, M.E. Socio-Economic Methodologies for Coastal Communities: The Example of Set Bagnet Communities in Bangladesh; Information Bulletin 10, DFID Post-Harvest Fisheries Project; DFID: Chennai, India, 1997.

39. Sunny, A.R.; Prodhan, S.H.; Ashrafuzzaman Sazzad, S.A.; Rahman, M.A.; Billah, M.M.; Hussain, M.; Rahman, M.; Haider, K.M.N.; Alam, M.T. Livelihoods and vulnerabilities of small-scale fishers to the impacts of climate variability and change: Insights from the coastal areas of Bangladesh. Egypt. J. Aquat. Biol. Fish. 2021, 25, 549-571. [CrossRef]

40. Sunny, A.R.; Prodhan, S.H.; Ashrafuzzaman Ahamed, G.S.; Sazzad, S.A.; Mithun, M.H.; Haider, K.M.N.; Alam, M.T. Understanding Livelihood Characteristics and Vulnerabilities of Small-scale Fishers in Coastal Bangladesh. J. Aquac. Res. Dev. 2021, 12, 635.

41. Kuddus, M.A.; Alam, M.J.; Datta, G.C.; Miah, M.A.; Sarker, A.K.; Sunny, M.A.R. Climate resilience technology for year round vegetable production in northeastern Bangladesh. Int. J. Agril. Res. Innov. Tech. 2021, 11, 29-36. [CrossRef]

42. Sunny, A.R.; Alam, R.; Sadia, A.K.; Miah, Y.; Hossain, S.; Mofiz, S.B. Factors affecting the Biodiversity and Human Well-Being of an Ecologically Sensitive Wetland of North Eastern Bangladesh. J. Coast. Zone Manag. 2020, 23, 471.

43. Rana, M.S.; Uddin, M.M.; Uddin, M.S.; Alam, M.T. Status of Aquaculture and Livelihood of Fish Farmers in Golapgonj Upazila under Sylhet District, Bangladesh. Int. J. Nat. Sci. 2016, 6, 66-74.

44. Sunny, A.R.; Islam, M.M.; Rahman, M.; Miah, M.Y.; Mostafiz, M.; Islam, N.; Hossain, M.Z.; Chowdhury, M.A.; Islam, M.A.; Keus, J.H. Cost effective aquaponics for food security and income of farming households in coastal Bangladesh. Egypt. J. Aquat. Res. 2019, 45, 89-97. [CrossRef]

45. Islam, M.M.; Khan, M.I.; Barman, A. Impact of novel coronavirus pandemic on aquaculture and fisheries in developing countries and sustainable recovery plans: Case of Bangladesh. Mar. Policy 2021, 131, 104611. [CrossRef]

46. Rabby, A.F.; Hossain, M.A.; Dey, T.; Alam, M.T.; Uddin, M.S. Fish Marketing System and Socio-Economic Status of Arotdars (Commission Agents) in North-Eastern Part of Bangladesh. Trends Fish. Res. 2019, 8, 23-30.

47. Sunny, A.R.; Islam, M.M.; Nahiduzzaman, M.; Wahab, M.A. Coping with climate change impacts: The case of coastal fishing communities in upper Meghna hilsa sanctuary of Bangladesh. In Water Security in Asia: Opportunities and Challenges in the Context of Climate Change; Babel, M.S., Haarstrick, A., Ribbe, L., Shinde, V., Dichti, N., Eds.; Springer: Berlin/Heidelberg, Germany, 2018; ISBN 978-3-319-54612-4. Available online: http:/ / www.springer.com/us/book/9783319546117 (accessed on 1 January 2018).

48. Alam, M.T.; Hussain, M.A.; Sultana, S.; Mazumder, S.K. Impact of Sanctuary on Fish Biodiversity and Production in Two Important Beels of Bangladesh. Adv. Biol. Res. 2017, 11, 348-356. [CrossRef]

49. Sunny, A.R. A review on the effect of global climate change on seaweed and seagrass. Int. J. Fish. Aquat. Stud. 2017, 5, 19-22.

50. Kawsar, M.A. Impact of Corona Virus on Fisheries: Bangladesh Perspective. Agrinews24.com. 2020. Available online: http: //www.agrinews24.com/impact-of-corona-virus-on-fisheries-bangladesh-perspective/ (accessed on 24 April 2020).

51. Rashid, H. Problems Arising in Fish Farming Due to Corona Disaster. BonikBarta. 2020. Available online: https://bonikbarta. net/home/news_description/229391/ (accessed on 12 June 2020).

52. Wang, X.; Yuen, K.F.; Wong, Y.D.; Li, K.X. How can the maritime industry meet Sustainable Development Goals? An analysis of sustainability reports from the social entrepreneurship perspective. Transp. Res. Part D Transp. Environ. 2020, 78, 102173. [CrossRef] 
53. De Bisthoven, L.J.; Vanhove, M.P.M.; Rochette, A.J.; Hugé, J.; Verbesselt, S.; Machunda, R.; Munishi, L.; Wynants, M.; Steensels, A.; Malan-Meerkotter, M.; et al. Social-ecological assessment of Lake Manyara basin, Tanzania: A mixed method approach. J. Environ. Manag. 2020, 267, 110594. [CrossRef]

54. Bayazid, Y. The Daudkandi model of community floodplain aquaculture in Bangladesh: A case for Ostrom's design principles. Int. J. Commons 2016, 10, 854-877. [CrossRef]

55. Hasan, M.M.; Hossain, B.S.; Alam, M.J.; Chowdhury, K.A.; Al Karim, A.; Chowdhury, N.M.K. The Prospects of Blue Economy to Promote Bangladesh into a Middle-Income Country. Open J. Mar. Sci. 2018, 8, 355. [CrossRef]

56. Hussain, M.G.; Failler, P.; Karim, A.A.; Alam, M.K. Major opportunities of blue economy development in Bangladesh. J. Indian Ocean Reg. 2018, 14, 88-99. [CrossRef]

57. MoFA. Blue Economy_Development of Sea Resources for Bangladesh. 2019. Available online: https://mofa.gov.bd/site/page/ 8c5b2a3f-9873-4f27-87612737db83c2ec/OCEAN/BLUE-ECONOMY--FOR-BANGLADESH (accessed on 31 October 2019).

58. Hunt, B.; Vincent, A.C. Scale and sustainability of marine bioprospecting for pharmaceuticals. AMBIO: J. Hum. Environ. 2006, 35, 57-64. [CrossRef]

59. World Bank. Bangladesh: Climate Change and Sustainable Development. Report No. 21104-BD; Rural Development Unit, South Asia Region, The World Bank (WB): Dhaka, Bangladesh, 2000; p. 95.

60. Chowdhury, M.T.H.; Sukhan, Z.P.; Hannan, M.A. Climate change and its impact on fisheries resource in Bangladesh. In Proceedings of the International Conference on Environmental Aspects of Bangladesh (ICEAB10), Kitakyushu, Japan, 4 September 2010.

61. Rahman, A.K.A. Freshwater Fishes of Bangladesh, 2nd ed.; Zoological Society of Bangladesh, Department of Zoology, University of Dhaka: Dhaka, Bangladesh, 2005; p. 394.

62. IUCN. Red List of Bangladesh, A Brief on Assessment Result 2015; International Union for Conservation of Nature: Dhaka, Bangladesh, 2015; 26p.

63. Haque, M.M.; Belton, B.; Alam, M.M.; Ahmed, A.G.; Alam, M.R. Reuse of fish pond sediments as fertiliser for fodder grass production in Bangladesh: Potential for sustainable intensification and improved nutrition. Agric. Ecosyst. Environ. 2016, 216, 226-236. [CrossRef]

64. Hossain, M.I. Climate Change: A Challenge to coastal agriculture in Bangladesh. In Planned Decentralisation: Aspired Development; World Bank: Dhaka, Bangladesh, 2013; pp. 60-65.

65. Chowdhury, A.H. Environmental impact of coal based power plant of Rampal on the Sundarbans (World Largest Mangrove Forest) and surrounding areas. MOJ Ecol. Environ. Sci. 2017, 2, 1-14. [CrossRef]

66. Chowdhury, A.R. Coast or Construction? The Daily Star. 2018. Available online: https://www.thedailystar.net/star-weekend/ environment/coast-or-construction-1587958 (accessed on 8 June 2018).

67. Mazid, M.A. Development of fisheries in Bangladesh. Policy 2002, 2, 3. 